\title{
АНАЛІЗ ПРИЧИН ВИРОБНИЧОГО ТРАВМАТИЗМУ У МЕДИЧНІЙ СФЕРІ ЯК ПІДГРУНТЯ ДЛЯ ЙОГО ПОПЕРЕДЖЕННЯ
}

\author{
О.П. Яворовський ${ }^{1}$ Ю.М. Скалецький${ }^{2}$ М.М. Риган ${ }^{3}$, \\ В.В. Майстренко ${ }^{4}$ А.К. Горваль², Р.П. Брухно1
}

\author{
${ }^{1}$ Національний медичний університет імені О.О. Богомольця (м. Київ) \\ ${ }^{2}$ ДУ «Інститут громадського здоров'я ім. О.М.Марзєєва НАМН України» (м. Київ) \\ ${ }^{3}$ Центр спортивної травматології та відновлювальної медищини Національного університету \\ фізичного виховання і спорту Украӥн, (м. Київ) \\ ${ }^{4}$ ДУ «Національний науково-дослідний інститут промислової безпеки і охорони праці, (м. Київ)
}

Вступ. Шкідливі і небезпечні умови пращі в охороні здоров'я серед іншого часто вимушують медичних працівників до пошуку роботи у інших закладах і галузях, до міграції у інші країни, а також негативно відбиваються на продуктивності їх діяльності та несуть загрозу безпеці пацієнтів.

Метою дослідження $\epsilon$ аналіз причин травматизму у фахівців охорони здоров'я.

Матеріали і методи. В роботі за допомогою бібліосемантичного та математичног методів, методу системного аналізу досліджувались причини виробничого травматизму у вітчизняній медичній cферi.

Результати. Детально проаналізовано причини виробничого травматизму в охорні здоров'я у період з 2006 по 2018 роки. Встановлено, що переважно виробничий травматизм з важкими наслідками в охороні здоров'я стається з причини організаційного характеру - 59 \%, на другому місці причини психофізіологічного характеру - 37,8 \% і на третьому місці причини технічного характеру - 3,2 \%. В цей же час причини виробничих травм зі смертельними наслідками у медичній сфері мали принципово інший розподіл: явно переважали причини психофізіологічного характеру - 78,2 \%, на другому місці - причини організаційного характеру - 20,6 \% і на третьому - причини технічного характеру - 1,2\%.

Висновки. У період з 2006 по 2018 роки серед причин виробничого травматизму у вітчизняній медичній сфері переважали причини організаційного характеру, а серед причини травм зі смертельними наслідками - причини психофізіологічного характеру. Значна частка жертв виробничого травмавтизму в охороні здоров'я з причин організаційного та технічного характеру пов'зана з експлуатацією, обслуговуванням та технічним станом транспортних заходів. Викликають стурбованість високі рівні виробничого травматизму, у тому числі зі смертельними наслідками, через незадовільні фізичні дані чи стан здоров'я медичних працівників, через їх низьку нервово-психічну стійкість, а також внаслідок протиправних дій інших осіб.

Ключові слова: охорона здоров'я, медичні працівники, причини виробничого травматизму.

Вступ. Виробничий травматизм в медичній сфері $\epsilon$ актуальною проблемою 3 двох причин. По-перше, працівники охорони здоров'я являють одну з найбільш чисельних професійних груп у переважній більшості країн, і за наявними даними медична сфера за нелетальним травматизмом, а відповідно і медико-соціальними та економічними втратами від цього випереджує такі техногенно небезпечні галузі, як сільське господарство, видобування вуглеводнів, транспортування і складування вантажів тощо [1]. По-друге, не можна забезпечити належний рівень безпеки пацієнтів без створення безпечних і здорових умов праці медичним працівникам $[2,3,4,5]$. Проблема виробничого травматизму в охороні здоров'я в Україні залишається все ще недостатньо вивченою. При цьому, що травматизм i витрати закладів охорони здоров'я, зумовлені нещасними випадками, зростають [6]. Соціально-культурна сфера та торгівля, куди входить i система охорони здоров'я, останніми роками стали «лідерами» за приростом виробничого травматизу, у тому числі і травматизму зі смертельними наслідками $[7,8]$.

Погані умови праці - це одна із значущих причин міграції медичних працівників через що бідні країни, і Україна $є$ тому підтвердження, практично інвестують у підготовку медичних кадрів для високорозвинутих країн [9]. Одна з наших останніх робіт за цим спрямуванням стосувалась тенденцій виробничого травматизму в охороні здоров'я [10].

Метою ж даного дослідження є аналіз причин травматизму в охороні здоров'я як 
передумови обгрунтування заходів 3 мінімізації виробничих ризиків для медичних працівників.

Матеріали та методи досліджень. В роботі аналізувались матеріали В003 щодо безпеки і гігієни праці медичних працівників, база даних Державної служби України 3 питань праці (2006 по 2018 роки) 3 виробничого травматизму за кодами причин, у якій традиційно реєструються нещасні випадки переважно 3 важкими i смертельними наслідками. Досліджувались також дані статистичних збірників Держстатистики «Травматизм на виробництві в Україні» в частині виробничого травматизму в охороні здоров'я, дані щодо виробничого травматизму в інших країнах, тематичні публікації. Методами досліджень були: бібліосемантичний, системний аналіз, математичні (відносні величини).

\section{обговорення.}

Результати дослідження та їх

При галузевому аналізі матеріалів Держстату щодо виробничого травматизму виявились його особливості в охороні здоров'я. У медичній галузі смертельний виробничий травматизм, пов'язаний 3 виробництвом, в окремі роки у десятки разів нижчий ніж смертельний виробничий травматизм у галузі в цілому. В економіці України разом і в переважній більшості сфер економічної діяльності це співідношення знаходиться на рівні 2,5.

Цей факт може свідчити про невраховані чи недооцінені фактори виробничого середовища та трудового процесу, що формують додаткові ризики для здоров'я i життя медичних працівників. Аналіз же причин виробничого травматизму загалом, на наш погляд, допоможе виявити ці фактори.

Співвідношення потерпілих внаслідок виробничого травматизму у медичній сфері за причинами різного характеру у період з 2006 по 2018 роки. За 13 років аналізованого періоду у вітчизняній охороні здоров'я важко травмовані 1149 медичних працівників і 335 із них смертельно (табл. 1). Реально ж ці цифри вищі оскільки дані Держпраці і Держстату України щодо виробничого травматизму дещо різняться. Про те в будь-якому випадку це великі медико-соціальні і економічні та моральні втрати держави, галузі, окремих закладів охорони здоров'я (303) і родин.

Таблиця 1

Виробничий травматизм в охороні здоров'я за характером причин (за інформацією бази даних Держпраці України з виробничого травматизму)

\begin{tabular}{|c|c|c|c|c|}
\hline \multirow{2}{*}{ Роки } & \multicolumn{3}{|c|}{ Характер причин } & \multirow{2}{*}{ Всього } \\
\cline { 2 - 4 } & Організаційні & Технічні & Психофізіологічні & \\
\hline 2018 & $38(4)$ & 0 & $27(19)$ & $65(24)$ \\
\hline 2017 & $48(1)$ & $2(0)$ & $42(30)$ & $92(31)$ \\
\hline 2016 & $34(3)$ & $3(0)$ & $26(15)$ & $63(18)$ \\
\hline 2015 & $23(4)$ & $2(0)$ & $30(24)$ & $55(28)$ \\
\hline 2014 & $48(2)$ & $2(0)$ & $51(23)$ & $101(26)$ \\
\hline 2013 & $39(2)$ & 0 & $40(28)$ & $79(30)$ \\
\hline 2012 & $73(7)$ & $6(1)$ & $27(11)$ & $106(19)$ \\
\hline 2011 & $34(5)$ & $3(0)$ & $33(22)$ & $70(27)$ \\
\hline 2010 & $66(9)$ & $1(0)$ & $33(20)$ & $100(29)$ \\
\hline 2009 & $50(4)$ & $4(0)$ & $43(20)$ & $97(24)$ \\
\hline 2008 & $64(12)$ & $6(1)$ & $35(22)$ & $105(35)$ \\
\hline 2007 & $86(4)$ & $3(1)$ & $21(14)$ & $110(19)$ \\
\hline 2006 & $75(12)$ & $5(1)$ & $26(14)$ & $106(27)$ \\
\hline Разом & $678(69)$ & $37(4)$ & $434(262)$ & $1149(335)$ \\
\hline
\end{tabular}

* - в дужках смертельні випадки

Оскільки значних відмінностей кількості потерпілих за окремі роки в охороні здоров'я не спостерігається, то для надійності висновків ми всі ці дані об’єднали в одну вибірку. Співвідношення потерпілих у медичній сфері за причинами різного характеру у період з 2006 по 2018 роки представлено на рисунках 1 і 2. 
Iз рис. 1 слідує, що найчастіше медичні працівники при виконанні професійних обов'язків важко травмуються через причини організаційного характеру - 59 \%, на другому місці за значимістю - причини психофізіологічного характеру - 37,8 \% і на третьому місці причини технічного характеру $-3,2 \%$.

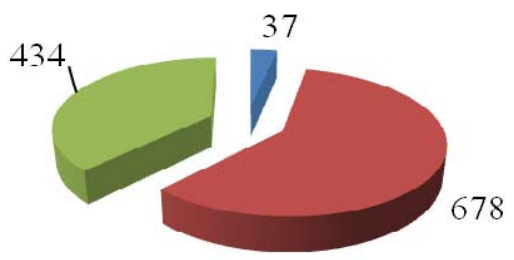

В цей же час травми зі смертельними наслідками у медичній сфері (рис. 2) найчастіше стаються через причини психофізіологічного характеру - 78,2 \%, на другому місці - причини організаційного характеру - 20,6 \% і на третьому - причини технічного характеру - 1,2\%.

Рисунок 1. Розподіл потерпілих внаслідок нещасних випадків у медичній сфері з причин організаційного, технічного та психофізіологічного характеру за період з 2006 по 2018 роки.

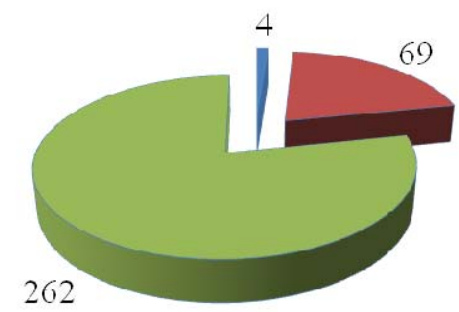

\author{
Причини НВ - технічні (4) \\ п Причини НВ - організаційні (69) \\ $\square$ Причини НВ - пспхо фізіологічні (262)
}

Рисунок 2. Розподіл потерпілих внаслідок нещасних випадків зі смертельними наслідками у медичній сфері з причин організаційного, технічного та психофізіологічного характеру за період з 2006 по 2018 роки.

Отже за привалюючими причинами в загальній кількості потерпілих від виробничого травматизму в охороні здоров'я $\epsilon$ причини організаційного характеру, а серед причин через, які сталися смертельні випадки - причини психофізіологічного характеру.

Розподіл постраждалих від виробничого травматизму працівників медичної сфери за причини організаційного характеру. Співідношення травмованих у медичній сфері за причини організаційного характеру наведено на рис. 3. Очевидно, що серед вказаних причин переважають нещасні випадки, пов'язані з транспортними засобами. Значна частка потерпілих пов'язана 3 порушенням правил безпеки руху - 497 осіб $(73,0 \%)$ і порушенням вимог безпеки під час експлуатації транспортних засобів - 72 особи (11\%), на третьому - збірна група «інші» - 56 осіб $(11,0 \%)$, на четвертому - порушення трудової і виробничої дисципліни - 26 осіб $(4,0 \%)$ і на п'ятому - порушення вимог безпеки під час експлуатації обладнання, устаткування, машин, механізмів тощо - 18 осіб $(3,0 \%)$.

Переважна кількість травмованих зі смертельними наслідками (рис. 4) пов'язана з порушенням правил безпеки руху - 46 осіб (67\%) та порушенням трудової і виробничої дисципліни - 7осіб (10,0\%), порушенням вимог безпеки під час експлуатації обладнання, устаткування, машин, механізмів - 6 осіб (9,0\%) . До групи групу «інші» причини віднесені 8 смертельно травмованих або $12,0 \%$.

Розподіл потерпілих внаслідок виробничого травматизму у медичній сфері $з$ причин технічного характеру. Розподіл потерпілих в охороні здоров'я 3 причин технічного характеру демонструють рисунки 5 та 6. Із рисунка 5 слідує, що в групі причин технічного характеру, як і в групі причин організаційного характеру, значна кількість нещасних випадків пов'язана з транспортом, але у даному випадку з його незадовільним технічним станом - 12 потерпілих $(33,0 \%)$. 
Помітною за внеском у виробничий виробництва - 4 особи (11\%). I нарешті травматизм $\epsilon$ причина, пов'язана 3 виділяється група «інші» - 15 травмованих конструктивними недоліками, недоскона- $(41,0 \%)$, котра потребує окремого розгляду. лістю, недостатньою надійністю засобів

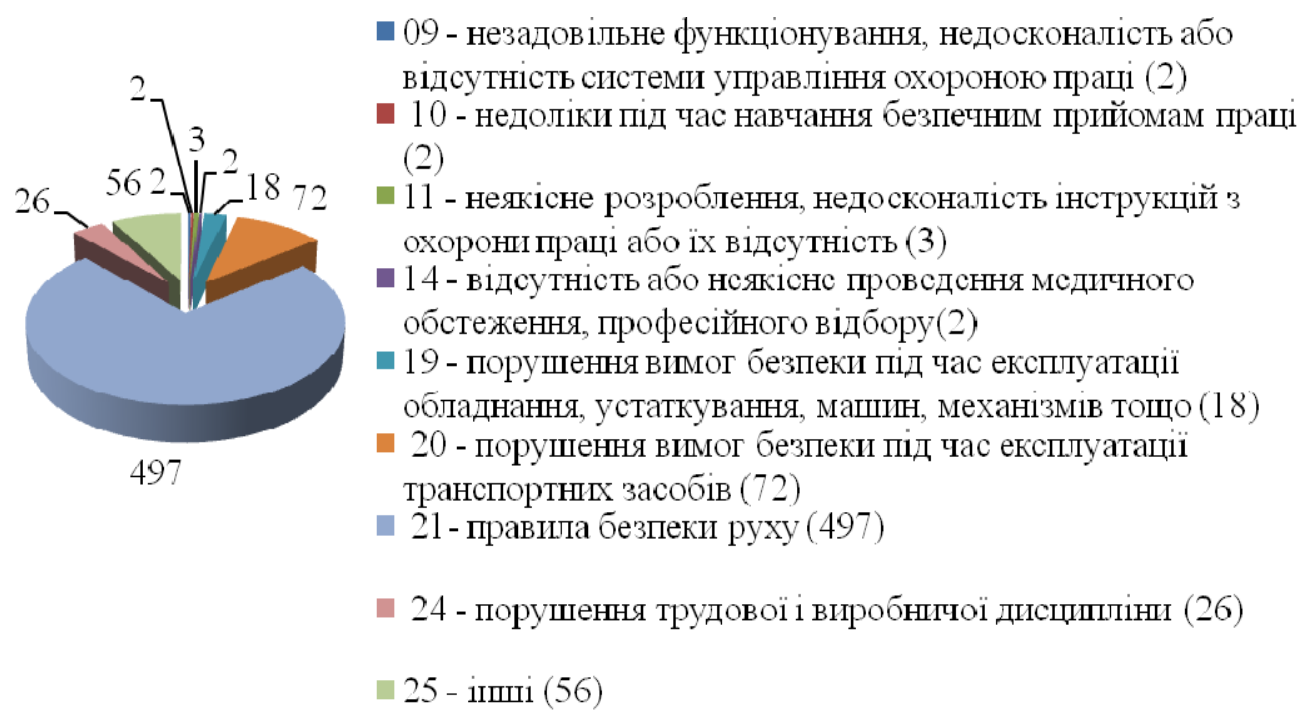

Рисунок 3. Розподіл потерпілих внаслідок нещасних випадків у медичній сфері 3 причин організаційного характеру за період з 2006 по 2018 роки.

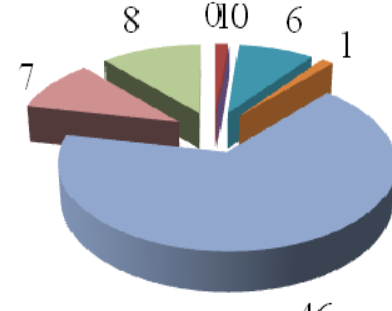

46

- 09 - незадовільне функціонування, недосконалість або відсутність системи управління охороною $(0)$ праці

- 10 - недоліки під час навчання безпечним припомам праці (1)

11 - неякісне розроблення, недосконалість інструкцій $з$ охорони праці або їх відсутність (0)

14 - відсутність або неякісне проведення медичного обстеження, професійного відбору (0)

19 - порушення вІмог безпеки під час експлуатаціі обладнання, устаткування, машин, механізмів

- 20 - порушення вимог безпеки під час експлуатаціі транспортнгх засобів (1)

- 21 - правила безпеки руху (46)

- 24 - порушення трудової і виробнпчої дисцпплінп (7)

25 - інші (8)

Рисунок 4. Розподіл смертельно травмованих внаслідок виробничого травматизму працівників охорони здоров’я з причин організаційного характеру за період з 2006 по 2018 рр.

Причинами 4-х випадків смертельних травм відповідно були визнані: конструктивні недоліки, недосконалість та недостатня надійність засобів виробництва; неякісне виконання будівельних робіт; незадовільний технічний стан транспортних засобів і збірна група причин - «інші». Загалом група потерпілих з причин технічного характеру найменш чисельна.

Розподіл потерпілих внаслідок виробничого травматизму у медичній сфері з причин психофізіологічного характеру. Дані щодо потерпілих у медичній сфері з цієї групи причин наведені на рисунках 7 i 8.

Основна частка травмованих працівників охорони здоров'я 3 причин психофіліологічного характеру припадая на незадовільні фізичні дані або стан здоров'я працівників - 120 осіб (28,0\%), на другому місці - травмування внаслідок протиправних дій інших осіб та низької нервово-психічної стійкості працівників - по 86 осіб (по 20,0\%), на третьому місці за значимістю незадовільний психологічний клімат $\mathrm{y}$ 
колективі - 59 осіб (13,0\%) і на четвертому 36 осіб (8,0\%). Чисельною є і група «інші» - на місці - особиста необережність потерпілих - цю групу доводиться 33 травмованих $(7,0 \%)$.

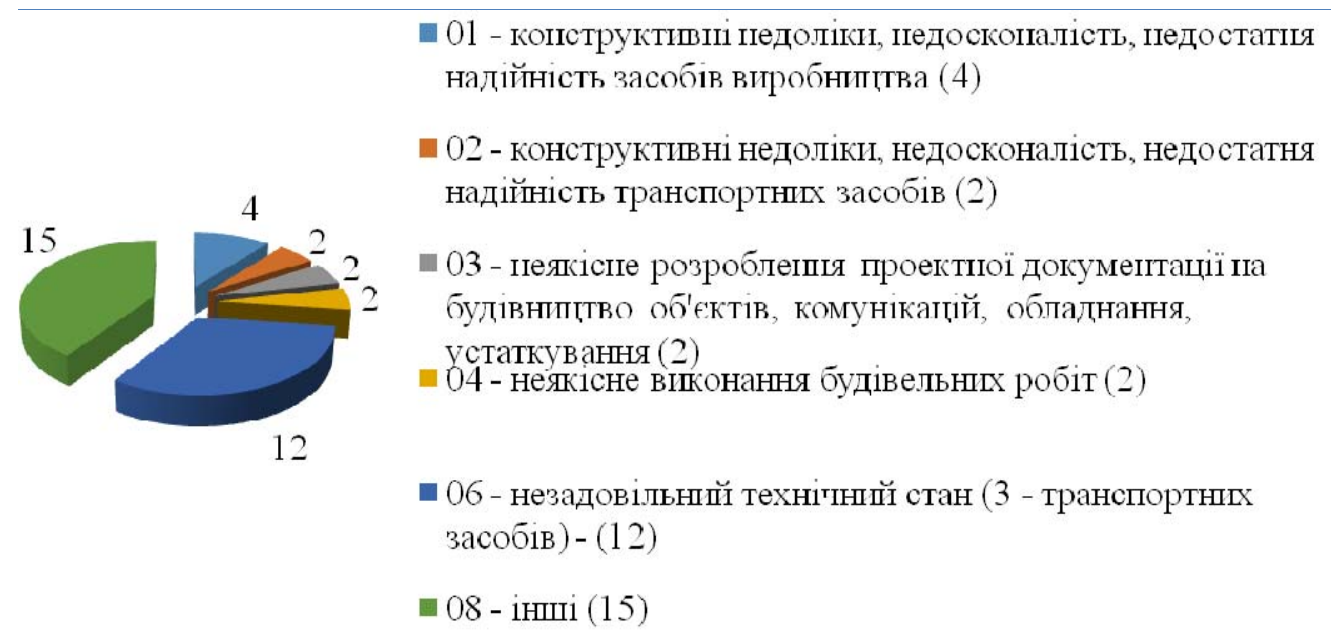

Рисунок 5. Розподіл потерпілих внаслідок нещасних випадків зі смертельними наслідками у медичній сфері з причин технічного характеру за період з 2006 по 2018 роки.

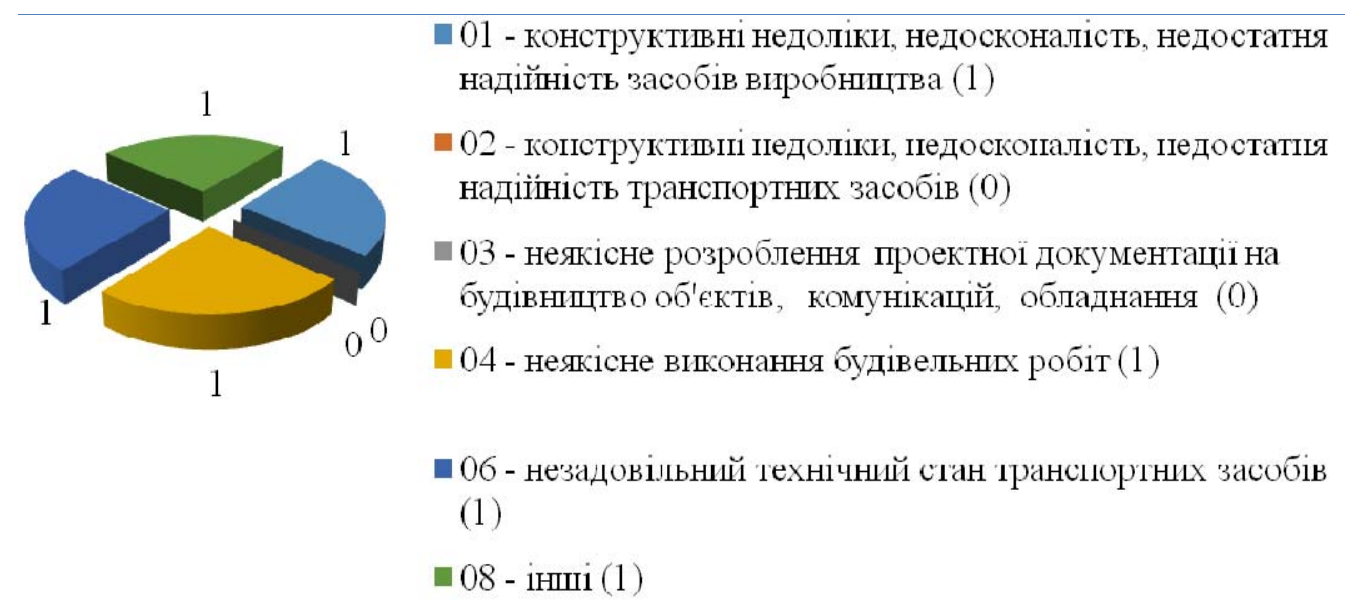

Рисунок 6. Розподіл потерпілих внаслідок нещасних випадків зі смертельними наслідками в охороні здоров'я з причин технічного характеру за період з 2006 по 2018 роки.

च 26 - алкогольне, наркотичне, токсикологічне отруєння (12)

Ш 27 - алкогольнс, наркотичне, токспкологічне сп'яніння (2)

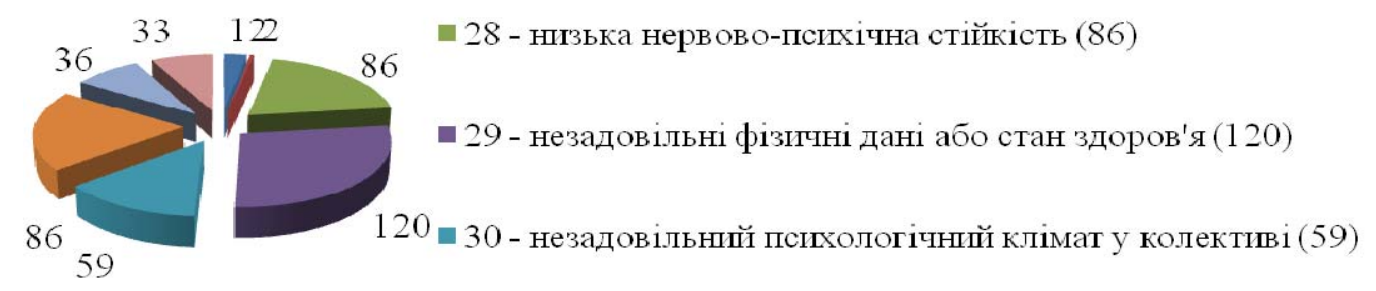

च 31 - травмування внаслідок протиправншх дій інших осіб (86)

ఐ 32 - особиста необережність потерпілого (36)

ш33 - інші (33)

Рис. 7. Розподіл потерпілих внаслідок нещасних випадків у медичній сфері з причин психофізіологічного характеру за період з 2006 по 2018 роки. 
Інша ситуація зі смертельно травмованими у закладах охорони здоров'я 3 причин психофізіологічного характеру (рис. 8). Як уже відмічалось тут значимість психофізіологічних причини виходить на перше місце - 262 особи. Як бачимо із рис. 8, найчастіше у цій групі причин медичні працівники помирали через незадовільні фізичні дані або стан здоров'я працівників 116 осіб (44,0\%), низьку нервово-психічну стійкість працівників - 84 особи $(32,0 \%)$ - i через травмування внаслідок протиправних дій інших осіб - 28 загиблих працівників галузі (11,0\%). За цією останньою причиною медична сфера лідирує серед всіх інших сфер економічної діяльності в Україні [6]. Насилля над медичними працівниками під час виконання ними своїх професійних обов'язків це актуальна також і у світі в цілому проблема [2,9 ]. Значна за чисельністю група «інші» - 19 осіб (8,0\%).

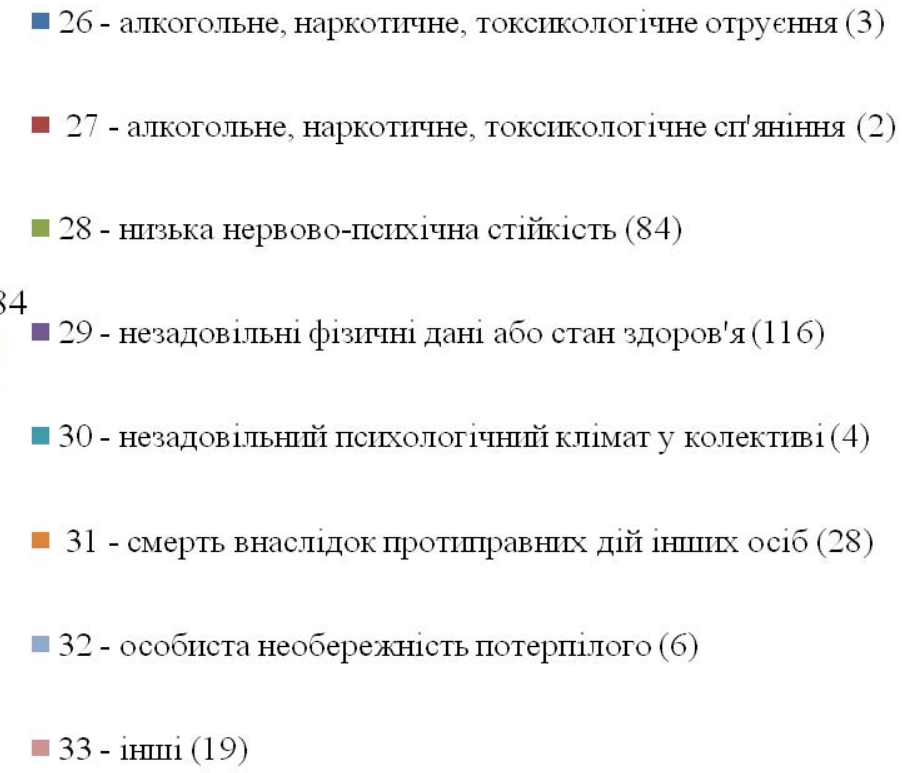

Рисунок 8. Розподіл потерпілих внаслідок нещасних випадків зі смертельними наслідками у медичній сфері з причин психофізіологічного характеру з 2006 по 2018 роки.

Високий рівень смертності на роботі працівників охорони здоров'я 3 причин психофізіологічного характеру протягом досліджуваного періоду свідчить про недостатню ефективність попереджувальних заходів, а скоріше ігнорування Держпраці і МО3 України зазначеної проблеми.

Аналізуючи причини виробничого травматизму психофізіологічного характеру в охороні здоров'я доречно додати, що психосоціальним виробничим ризикам світовою спільнотою останнім часом приділяється велика увага. Всесвітній день охорони праці у 2016 році проходив під гаслом «Стрес на робочому місці: колективний виклик». Принагідно також нагадати про парадигму «другої жертви» в охороні здоров'я, під котрою розуміють психоемоційний стан медичного працівника, помилка якого при наданні медичної допомоги спричинила шкоду здоров'ю пацієнта чи навіть зумовила його смерть [11]. Вважається, що у медичного працівника, який виступає «другою жертвою» розвивається симптомокомплекс, аналогічний посттравматичному синдрому учасників бойових дій i для багатьох медичних працівників - періодичні спогади про інцидент безпеки пацієнта сприяють емоційному вигоранню, депресії та суїцидальній ідеї [12]. Питання розробки заходів реабілітації і правового захисту «другої жертви» широко обговорюються у медичному середовищі [5].

Однак ні зазначені в статті, i, ні інші питання безпеки та гігієни праці медичних працівників не знаходяться у полі зору профільного міністерства [13].

Не зважаючи на те, що 2020 рік ще не завершився і відсутні остаточні дані щодо нещасних випадків в медичному середовищі, обумовлених вірусом SARS-CoV-2, відмітимо, 
що за питомою вагою захворілих на коронавірусну хворобу COVID-19 медичних працівників (близько 20\% серед усіх захворілих) Україна випереджає інші країни Європи i світу, ще раз підтверджуючи актуальність проблеми охорони праці у вітчизняній медицині [14].

Враховуючи динаміку захворюваності медичних працівників на кронавірусну хворобу COVID-19 і їх смертності від цієї хвороби в Україні безсумнівно, що за підсумками 2020 року, праця у медичній сфері буде оцінюватися однією найнебезпечніших. Тому недопустимо, щоб питання створення здорових і безпечних умов праці в охороні здоров'я і надалі залишались поза увагою М03, Держпраці і Державної служби України 3 питань надзвичайних ситуацій.

\section{Висновки}

1. У період з 2006 по 2018 роки серед причин важких травм працівників у вітчизняній медичній сфері переважали причини організаційного характеру - 59 \%, на другому місці причини психофізіологічного характеру - 37,8 \% i на третьому місці причини технічного характеру - 3,2 \%. В той же час причини травм зі смертельними наслідками в охороні здоров'я мали принципово інший розподіл: явно переважали причини психофізіологічного характеру - 78,2 \%, на другому місці - причини організаційного характеру - 20,6 \% i на третьому - причини технічного характеру $1,2 \%$.

2. Значна частка жертв виробничого травмавтизму в охороні здоров'я 3 причин організаційного та технічного характеру пов'зана з експлуатацією, обслуговуванням та технічним станом транспортних заходів потребує невідкладного внесення змін у чинне законодавство і реалізації організаційних заходів на рівні профільного міністерства 3 попередження цих причин травматизму.

\section{Література}

1. Employer-reported workplace injuries and illnesses - 2018. Bureau of Labor Statistics, U.S. Department of Labor, Survey of Occupational Injuries and Illnesses, in cooperation with participating state agencies. 2019.
3. Висока частка смертей фахівців охорони здоров'я під час виконання ними службових обов'язків 3 причин психофізіоло-гічного характеру, а саме через незадовільні фізичні дані або стан здоров'я працівників, а також через низьку нервово-психічну стійкість працівників свідчить про недооцінку М03 України проблем, пов'язаних зі здоров'ям своїх працівників, від стану здоров'я i працездатності котрих залежить значною мірою здоров'я українського народу.
4. Найвищі
рівні
виробничого

травматизму, у тому числі і смертельного, у працівників охорони здоров'я у порівнянні 3 іншими працівниками внаслідок протиправних дій інших осіб потребують більш глибокого вивчення цієї проблеми i розробки та реалізації заходів з її мінімізації.

5. Не лише травматизм, пов'язаний 3 виробництвом, але й виробничий травматизм взагалі потребує належної уваги держави, роботодавців, профсоюзів 3 метою його мінімізації.

6. Шкідливість і небезпека умов праці в охороні здоров'я для працівників медичної галузі недооцінена, заходи з оздоровлення виробничого середовища у лікарняних закладах вживаються недостатні, що серед іншого часто вимушує медичних працівників до пошуку роботи у інших закладах і галузях, до міграції у інші країни, а також негативно відбивається на продуктивності їх діяльності та несе загрозу безпеці пацієнтів.

7. Результати цих та інших наших досліджень 3 оцінки рівнів, динаміки та причин виробничого травматизму в охороні здоров'я доцільно використати як основу для обгрунтування та запровадження заходів 3 підвищення безпеки i покращення гігієни праці медичних працівників.

8. Наявність доказової бази щодо існування проблеми не гарантує їі врахування при формуванні політики чи прийняті управлінських рішень. Тобто відсутні, по крайній мірі в охороні здоров'я, інструменти ранжування і пріоритизації проблем.

https://www.bls.gov/news.release/pdf/osh.pdf

(Mode of Access: 19.07.2020).

2. Занятость в области здравоохранения и экономический рост. Записка Генерального секретаря. Семьдесят вторая сессия Генеральной Ассамблеи ООН. 2017. A/72/378. URL : 
https://undocs.org/pdf?symbol=ru/A/72/378 .pdf (Mode of Access : 19.07.2020).

3. Глобальные действия по обеспечению безопасности пациентов. Резолюция 72 Всемирной Ассамблеи здравоохранения. WHA72.6. 2019. 8 р. URL : https://apps.who.int/gb/ebwha/pdf files/WHA72/A72 R6-ru.pdf (Mode of Access: 26.07.2020)

4. Tokyo Declaration on Patient Safety / Third Global Ministerial Summit on Patient Safety, 14 April 2018, Tokyo, Japan. 2 p. URL : https://www.mhlw.go.jp/file/06-Seisakujouhou10800000-Iseikyoku/0000204005.pdf (Mode of Access : 2.06.2020).

5. Jeddah Declaration on Patient Safety. 2019. URL : https://www.bundesgesundheitsministerium.de/filea dmin/Dateien/3_Downloads/P/Patientensicherheit/P SS_2019/Patientensicherheit_Erklaerung_Dschidda_2 019.pdf (Mode of Access : 26.07.2020).

6. Травматизм на виробництві в Україні у 2017 році. Статистичний збірник. Державна служба статистики України. КИїВ - 2018. URL : http://www.ukrstat.gov.ua/druk/publicat/kat u/201 8/zb/05/zb tv 2017.pdf. (Mode of Access : 19.07.2020).

7. Мітіна Н.Б. Дослідження стану травматизму та рівня професійної захворюваності на промислових об'єктах України. Мітіна Н.Б., Бабенко О.Ю., Воробйова Л.О. , Малиновська Н.В. Строительство, материаловедение, машиностроение. Серия: Безопасность жизнедеятельности. Вып. 105 - 2018. C. $139-147$.

8. Виробничий травматизм в Україні за 2019 рік. Державна служби України з питань праці. 2020.

\section{References}

1. Employer-reported workplace injuries and illnesses - 2018. (2019). Bureau of Labor Statistics, U.S. Department of Labor, Survey of Occupational Injuries and Illnesses, in cooperation with participating state agencies. URL: https://www.bls.gov/news.release/pdf/osh.pdf (Mode of Access: 19.07.2020).

2. Zanyatost $\mathrm{v}$ oblasti zdravoohraneniya $\mathrm{i}$ ekonomicheskiy rost. Zapiska Generalnogo sekretarya. Semdesyat vtoraya sessiya Generalnoy Assamblei OON. 2017. A/72/378. URL: https://undocs.org/pdf?symbol=ru/A/72/378.pdf (Mode of Access : 19.07.2020).

3. Globalnyie deystviya po obespecheniyu bezopasnosti patsientov. Rezolyutsiya 72 Vsemirnoy Assamblei zdravoohraneniya. WHA72.6. 2019. 8 p. URL: $\quad$ https://apps.who.int/gb/ebwha/pdf files/WHA72/A7 2 R6-ru.pdf Mode of Access: 26.07.2020).

4. Tokyo Declaration on Patient Safety / Third Global Ministerial Summit on Patient Safety, 14 April
URL: https://www.sop.com.ua/news/2424virobnichiy-travmatizm-v-ukrani-za-2019-

rk?from=PW_Click desktop_podsek\&token $=224767 \mathrm{~b} 0$ -bcaa-11a0-cd7d-

2d011b84b213\&ttl=7776000\&ustp=W (Mode of Access : 19.07.2020).

9. Human resources for health in the WHO European Region. WHO Regional Office for Europe. 2005. URL

http://www.euro.who.int/_data/assets/pdf_file/000 7/91474/E88365.pdf (Mode of Access : 19.07.2020).

10.Виробничий травматизм в медичній галузі: стан і тенденції. Сердюк А.М., Яворовський О.П., Скалецький Ю.М. та інш. Журнал Національної академії медичних наук України у № 3-4 за 2017 р. С. $47-54$.

11.The Impact of Adverse Events on Clinicians: What's in a Name? Wu AW, Shapiro J, Harrison R, Scott SD, Connors C, et al. J Patient Saf. 2017. Nov 4. URL : https://www.ncbi.nlm.nih.gov/pubmed/29112025

(Mode of Access : 19.07.2020).

12. Stewart Kevin. Supporting "second victims" is a system-wide responsibility. Kevin Stewart, Rebecca Lawton, Reema Harrison. British Medical Journal. 2015;350:h2341.

13. Гігієна і охорона праці медичного персоналу в умовах подолання пандемії COVID-19 (перше повідомлення). О.П.Яворовський, А.В.Шкурба, Ю.М.Скалецький, Р.П. Брухно, Л.В. Харчук та інш. Довкілля та здоров'я. 2020. № 3. (рукопис).

14.Селявін Дмитро. Чоботарі без чобіт. Охорона праці.- № 10.- 2017. - С. 20-22.

2018, Tokyo, Japan. 2 p. URL : https://www.mhlw.go.jp/file/06-

Seisakujouhou10800000-Iseikyoku/0000204005.pdf (Mode of Access: 2.06.2020).

5. Jeddah Declaration on Patient Safety. 2019. URL: https://www.bundesgesundheitsministerium.de/filea dmin/Dateien/3 Downloads/P/Patientensicherheit/P SS 2019/Jeddah-Declaration_GER.pdf (Mode of Access: 26.07.2020).

6. Travmatizm na virobnitstvi v Ukrayini u 2017 rotsi. (2018). Statistichniy zbirnik. Derzhavna sluzhba statistiki Ukrayini. Kiyiv. URL: http://www.ukrstat.gov.ua/druk

Lpublicat/kat u/2018/zb/05/zb tv 2017.pdf (Mode of Access : 19.07.2020).

7. Mitina, N.B., Babenko, O.Yu., Vorobyova, I.O., Malinovska, N.V. (2018). Doslidzhennya stanu travmatizmu ta rivnya profesiynoyi zahvoryuvanosti na promislovih ob'ektah ukrayini. Stroitelstvo, materialovedenie, mashinostroenie. Seriya: Bezopasnost zhiznedeyatelnosti. V. 105. 139-147. 
8. Virobnichiy travmatizm v ukrayini za 2019 rik. (2020). Derzhavna sluzhbi Ukrayini z pitan pratsi. URL: $\quad$ https://www.sop.com.ua/news/2424virobnichiy-travmatizm-v-ukrani-za-2019-rk?from=PW Click desktop_podsek\&token $=224767 \mathrm{~b} 0$-bcaa$11 \mathrm{a} 0$-cd7d2d011b84b213\&ttl=7776000\&ustp $=\mathrm{W}$ (Mode of Access : 19.07.2020).

9. Human resources for health in the WHO European Region. (2005).WHO Regional Office for Europe. URL: https://www.euro.who.int/data/assets/pdf file/000\%207/91474/E88365.pdf

(Mode of Access : 19.07.2020).

10. Serdyuk, A.M., Yavorovskiy, O.P., Skaletskiy, Yu.M. et al. (2017). Virobnichiy travmatizm v medichniy galuzi: stan i tendentsiyi. Zhurnal natsionalnoyi akademiyi medichnih nauk Ukrayiny. 3-4. $47-54$.
11. Wu, A.W., Shapiro, J, Harrison, R, Scott, S.D., Connors, C., et al. (2017). The Impact of Adverse Events on Clinicians: What's in a Name? J Patient Saf. 4. URL : https://www.ncbi.nlm.nih.gov/pubmed/29112025 (Mode of Access : 19.07.2020).

12. Stewart, K., Lawton, R., Harrison, R. (2015). Supporting "second victims" is a system-wide responsibility. British Medical Journal; 350: h2341.

13. Yavorovskiy, O.P., Shkurba, A.V., Skaletskiy, Yu.M., Bruhno, R.P., Harchuk, L.V. et al. (2020). Gigiena i ohorona pratsi medichnogo personalu $\mathrm{V}$ umovah podolannya pandemiyi COVID-19 (pershe povidomlennya). Dovkillya ta zdorov'ya. 3. (Article in Press).

14. Selyavin Dmitro. (2017). Chobotari bez chobit. Ohorona pratsi. 10. $20-22$.

\title{
АНАЛИЗ ПРИЧИН ПРОИЗВОДСТВЕННОГО ТРАВМАТИЗМА В МЕДИЦИНСКОЙ СФЕРЕ КАК ОСНОВА ДЛЯ ЕГО ПРЕДУПРЕЖДЕНИЯ
}

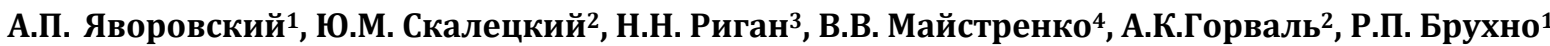

\author{
${ }^{1}$ Национальный медицинский университет имени Богомольца (г. Киев) \\ ${ }^{2}$ ДУ «Институт общественного здоровья им. Марзеева НАМН Украины ( (2. Киев) \\ ${ }^{3}$ Центр спортивной травматологии и восстановительной медицины Национального университета \\ физического воспитания и спорта Украины (2. Киев) \\ ${ }_{4}^{4} Г У$ «Национальный научно-исследовательский институт промышленной безопасности и охраны труда» \\ (2. Киев)
}

Введение. Вредные и опасные условия труда в здравоохранении среди прочего часто вынуждают медицинских работников к поиску работы в других учреждениях и отраслях, к миграции в другие страны, а также негативно отражаются на производительности их деятельности и несут угрозу безопасности пациентов.

Целью исследования является анализ причин травматизма в здравоохранении.

Материал и методы. $B$ работе с помощью библиосемантичного и математических методов, метода системного анализа исследовались причины производственного травматизма в отечественной медицинской сфере.

Результаты. Детально проанализированы причины производственного травматизма в здравоохранении в период с 2006 по 2018 годы. Установлено, что в основном производственный травматизм с тяжелыми последствиями в здравоохранении происходит по причине организационного характера - 59\%, на втором месте - причины психофизиологического характера - 37,8\% и на третьем месте причины технического характера - 3,2\%. В это же время причины производственных травм со смертельным исходом в медицинской сфере имели принципиально иное распределение: явно преобладали причины психофизиологического характера - 78,2\%, на втором месте - причины организационного характера - 20,6\% и на третьем - причины технического характера - 1,2\%.

Выводы. В период с 2006 по 2018 годы среди причин производственного травматизма в отечественной медицинской сфере преобладали причины организационного характера, а среди причине травм со смертельным исходом - причины психофизиологического характера. Значительная часть жертв производственного травмавтизму в здравоохранении из причин организационного и технического характера сопряжена с эксплуатацией, обслужсиванием и техническим состоянием транспортных средств. Вызывают обеспокоенность высокие уровни производственного травматизма, в том числе со смертельным исходом, из-за неудовлетворительных физических данных или состояния здоровья медицинских работников, из-за их низкой нервно-психической устойчивости, а также в результате противоправных действий других лиц.

Ключевые слова: здравоохранение, медицинские работники, причины производственного травматизма. 


\title{
ANALYSIS OF THE CAUSES OF OCCUPATIONAL INJURIES IN THE MEDICAL FIELD AS A BASIS FOR ITS PREVENTION
}

\section{O.P. Yavorovsky ${ }^{1}$, Y.M. Skaletsky ${ }^{2}$, M.M. Rygan ${ }^{3}$, V.V. Maistrenko ${ }^{4}$, A.K. Gorval ${ }^{\text {, }}$, R.P. Brukhno ${ }^{1}$}

\author{
1 Bogomolets National Medical University (Kyiv) \\ 2 SI «O.M. Marzieiev Institute for Pablic Health NAMS of Ukraine» (Kyiv) \\ ${ }^{3}$ National University of Ukraine on Physical Education and Sport (Kyiv) \\ ${ }^{4}$ SI«National Scientific and Research Institute of Industrial Safety and Occupational Safety and Health» (Kyiv)
}

Introduction. Harmful and dangerous working conditions in health care, among other things, often force health workers to look for work in other institutions and industries, to migrate to other countries, as well as negatively affect their productivity and pose a threat to patient safety.

The purpose of the study is to analyze the causes of injuries in health care.

Materials and methods. The causes of occupational injuries in the domestic medical sphere were investigated in the work with the help of bibliosemantic and mathematical methods, the method of system analysis.

Results. The causes of occupational injuries in health care in the period from 2006 to 2018 are analyzed in detail. It was found that mainly occupational injuries with serious consequences in health care occur due to organizational nature - 59\%, in second place for psychophysiological reasons - 37.8\% and in third place for technical reasons - 3.2\%. At the same time, the causes of industrial injuries with fatal consequences in the medical field had a fundamentally different distribution: clearly dominated by causes of psychophysiological nature - 78.2\%, in second place - organizational reasons - 20.6\% and in third place - technical reasons - 1, 2\%.

Conclusions. In the period from 2006 to 2018, organizational causes prevailed among the causes of occupational injuries in the domestic medical sphere, and among the causes of fatal injuries - psychophysiological causes. A significant proportion of victims of occupational injuries in health care for organizational and technical reasons are related to the operation, maintenance and technical condition of transport activities. High levels of occupational injuries, including fatalities, due to unsatisfactory physical condition or health status of health care workers, their low mental health stability, and the wrongful acts of others are a cause for concern.

Key words: health care, medical workers, causes of occupational injuries.

Конфлікт інтересів: відсутній.

Conflicts of interest: authors have no conflict of interest to daclare.

\section{Відомості про авторів:}

Яворовський О.П. A, $C, D, E, F$ доктор медичних наук, професор, академік НАМН України, завідувач кафедри гігієни та екології №2 Національного медичного університету імені О.О.Богомольця, м. Київ;

Скалецький Ю.М. $A, B, C, D, E, F$ доктор медичних наук, професор завідувач лабораторії безпекових стратегій в охороні здоров'я, ДУ «Інститут громадського здоров'я ім. О.М. Марзєєва НАМН України» , м. Київ;

Риган М.М. ${ }^{B, C}, D, E$ кандидат медичних наук науковий співробітник Національного університету фізичного виховання і спорту України, м. Київ;

Майстренко В.В. ${ }^{B, C}, D, E$ кандидат технічних наук, завідувач наукової лабораторії інформаційних систем ДУ «Національний науково-дослідний інститут промислової безпеки і охорони праці», , м. Київ;

Горваль А.К. $B, C, D, E$ кандидат медичних наук, науковий співробітник ДУ «Інститут громадського здоров'я ім. О.М. Марзєєва НАМН України» , м. Київ;

Брухно Р.П. B, C, D, E кандидат медичних наук асистент кафедри гігієни та екології №2 Національного медичного університету імені О.О.Богомольця, м. Київ

$A$ - концепція та дизайн дослідження; $B$ - збір даних; $C$ - аналіз та інтерпретація даних;

$D$ - написання статmi; $E$ - редагування статmі; F- остаточне затвердження статті.

\section{Сведения об авторах:}

Яворовский А.П. доктор медицинских наук, профессор, академик НАМН Украины, заведующий кафедрой гигиены и экологии №2 Национального медицинского университета имени Богомольца, г.. Киев;

Скалецкий Ю.М. доктор медицинских наук, профессор заведующий лабораторией безопасности стратегий в здравоохранении, ГУ «Институт общественного здоровья им. А.Н. Марзеева НАМН Украины »

Риган М.М. кандидат медицинских наук научный сотрудник Национального университета физического воспитания и спорта Украины, Киев 
Майстренко В.В. кандидат технических наук заведующий лаборатории информационных систем ГУ «Национальный научно-исследовательский институт промышленной безопасности и охраны труда», Киев.

Горваль А.К. кандидат медицинских наук, научный сотрудник ГУ «Институт общественного здоровья им. А.Н. Марзеева НАМН Украины », Киев.

Брухно Р.П. кандидат медицинских наук ассистент кафедры гигиены и экологии №2 Национального медицинского университета имени Богомольца, г.. Киев;

\section{Information about authors:}

Yavorovsky A.P., A, C, D, E, F MD DSc, Prof., Academician of NAMS of Ukraine, Head of the Department of Hygiene and Ecology №2 of the Bogomolets National Medical University, Kyiv

Skaletsky Y.N., $A, B, C, D, E, F$ MD DSc, Prof., Head of the laboratory of safety strategies in health care of the SI «O.M. Marzieiev Institute for Pablic Health NAMS of Ukraine», Kyiv

Regan M.M., ${ }^{B, C}, D, E$ MD DPh, researcher of the National University of Ukraine on Physical Education and Sport, Kyiv

Maistrenko V.V., ${ }^{B, C}, D, E$ DPh, Head of the information systems laboratory of the SI «National Scientific and Research Institute of Industrial Safety and Occupational Safety and Health», Kyiv

Gorval A.K., B, C, D, E MD DPh, researcher of the SI «O.M. Marzieiev Institute for Pablic Health NAMS of Ukraine», Kyiv

Brukhno R.P., ${ }^{B,} C, D, E$ MD DPh, assistant of the Department of Hygiene and Ecology №2 of the Bogomolets national medical university, Kyiv

$A$ - research concept and design; $B$ - collection and/or assembly of data; $C$ - data analysis and interpretation;

$D$ - writing the article; $E$ - critical revision of the article; $F$ - final approval of the article.

Адреса для листування: вул. Московська, 45/1, буд. 33, м. Київ 01015 